\title{
REPRESENTASI SCHIZHOPHRENIC TOKOH UTAMA DALAM NOVEL NAPAS MAYAT KARYA BAGUS DWI HANANTO
}

\author{
Teguh Yuliandri Putra \\ Program Studi Pendidikan Bahasa dan Sastra Indonesia \\ STKIP Muhammadiyah Sorong-Papua Barat \\ teguhputra559@yahoo.com
}

\begin{abstract}
Abstrak: Penelitian ini mendeskripsikan tentang representasi gejala schizophrenic yang dialami tokoh utama dalam novel Napas Mayat karya Bagus Dwi Hananto. Permasalahan inti yang digambarkan dalam novel ini adalah gambaran terpecahnya kepribadian seseorang, sehingga memicu terjadinya penyimpangan. Penelitian ini menggunakan pendekatan kualitatif sedangkan, metode dalam penelitian ini menggunakan metode deskriptif yakni cara yang dilakukan dalam penelitian ini untuk mengungkap fakta-fakta yang tampak atau mengungkap data dengan cara memberi deskripsi yang mendalam dan merujuk pada interpretasi yang menggambarkan atau melukiskan keadaan subjek atau objek. Adapun permasalahan yang diteliti adalah representasi reaksi schizophrenic yang dialami tokoh utama yang ditandai dalam tiga wujud reaksi, di antaranya (1) schizophrenic hebephrenic, (2) schizophrenic catatonic, (3) schizophrenic paranoid. Hasil penelitian ini berupa gambaran kejiwaan tokoh Aku dalam Novel Napas Mayat yang direpresentasikan melalui perspektif patologi sosial/penyimpangan sosial. Patologi sosial dapat diartikan sebagai "alat bedah" untuk mengukur tingkat penyimpangan psikologis tokoh Aku yang mengalami pola gangguan kecemasan di dalam kehidupan sosialnya. Tiga wujud reaksi yang tersebut di atas menjadi penjelas tingkatan gejala schizophrenic yang dialami oleh tokoh aku dalam Novel Napas Mayat karya Bagus Dwi Hananto.
\end{abstract}

Kata kunci: scizhophrenic, hebephrenic, catatonic, paranoid

Abstract: This study describing the schizophrenic symptoms represented by the main character of Napas Mayat, a novel written by Bagus Dwi Hananto. The main problem of the study was the personality split of an individual which eventually resulted in personality deviation. This study applied qualitative approach, while the method was descriptive which was an attempt to reveal visible facts or data by in-depth description and reference of interpretation which described the subject or object. The issue observed in this study was the representation of schizophrenic reaction experienced by the main character which signed with three different reactions, namely (1) schizophrenic hebephrenic, (2) schizophrenic catatonic, (3) schizophrenic paranoid. Result of the study was in the form of psychological description of the character Aku (Me) in the novel of Napas Mayat which also was represented through pathological social of social deviation perspective. The pathological social can be comprehended as the surgical instrument to measure the psychological deviation of the character Aku (Me) which undergone the anxiety disturbance within his social life. The three aforementioned reaction forms function as symptoms level clarification of schizophrenic suffered by the character of Aku (Me) from the novel of Napas Mayat written by Bagus Dwi Hananto.

Keywords: scizhophrenic, hebephrenic, catatonic, paranoid 


\section{PENDAHULUAN}

Karya sastra merupakan luapan spontan dari perasaan yang kuat, cermin emosi yang mendalam, yang kemudian direduksi dalam penciptaan melalui pemikiran. Dalam kehidupan masyarakat terdapat berbagai macam permasalahan sosial yang biasanya memberikan pengaruh dan tercermin di dalam karya sastra. Intinya, karya sastra merupakan cerminan kehidupan nyata. Sebuah karya sastra haruslah mengandung nilai-nilai luhur sosial yang dapat dijadikan oleh manusia sebagai acuan dan pedoman dalam kehidupan nyata. Hal ini sejalan dengan pendapat Suyasa (2004: 9) yang menjelaskan bahwa karya sastra mempunyai andil yang cukup besar dalam menyumbangkan buah perenungan, pemikiran serta menawarkan berbagai solusi terhadap masalah-masalah yang terjadi pada manusia dalam wujud tindakan perilakunya sebagai manusia individual maupun sebagai manusia sosial.

Usaha untuk memperoleh pemahaman mengenai prilaku manusia bukan hanya dimaksudkan untuk melampiaskan hasrat ingin tahu saja, tetapi juga diharapkan bermanfaat bagi peningkatan kualitas hidup manusia. Dalam kehidupan sehari-hari, semua orang akan menemui kesulitan dalam memberikan suatu dikotomi (pembagian atas dua kelompok yang saling bertentangan) yang jelas dan tepat antara kecemasan dan ketakutan. Rasa cemas selalu dicampuradukkan dengan rasa takut. Hal ini sejalan dengan pendapat Yoseph (dalam Sobur, 2013: 345) yang menyebutkan bahwa dalam rasa takut, seseorang menyadari bahaya yang sedang mengancam keselamatan dirinya. Penderitanya bahkan didorong dan diperkuat oleh situasi yang mengancam tersebut. Persepsi-persepsi indra akan menjadi lebih tajam, sehingga bisa menemukan jalan dan cara pemecahan yang sungguh disadari.

Fenomena penyimpangan psikosis pada umumnya dapat muncul dari rasa takut akan ancaman yang berlebihan terhadap keselamatan dirinya dan bisa juga disebabkan oleh ketidakmampuan seseorang dalam mengontrol amarah. Anggapan umumnya adalah bahwa orang yang merasa tidak enak dan terganggu akan cenderung menjadi marah dan agresif. Hal ini sejalan dengan pemikiran Novaco (dalam Sobur, 2013: 414) yang mengemukakan bahwa amarah bisa dipahami sebagai reaksi tekanan perasaan. Maksudnya ialah bahwa orang cenderung menjadi marah dan terdorong menjadi agresif jika harus menghadapi keadaan yang mengganggunya.

Tidak hanya terjadi di dunia nyata, penyimpangan-penyimpangan psikologis juga sering menjadi topik cerita dalam suatu karya sastra, seperti pada novel terjemahan Love Abuse karya Laurentia Mira yang mengisahkan tentang rekayasa pembunuhan akibat trauma seksual di dalam balutan cinta. Ketika para penikmat sastra membaca suatu karya sastra, pada hakikatnya mereka bertujuan menikmati, mengapresiasi, atau bahkan mengevaluasi karya-karya tersebut. Hal ini berarti mereka bergumul dengan para tokoh dan penokohan yang terdapat di dalam karya-karya tersebut. Para tokoh rekaan ini menampilkan berbagai watak dan perilaku yang terkait dengan kejiwaan dan pengalaman psikologis atau konflik-konflik sebagaimana dialami oleh manusia di dalam kehidupan nyata. Problem-problem kejiawaan dalam sebuah karya sastra dapat berupa konflik, kelainan perilaku, dan bahkan kondisi psikologis yang lebih parah, sehingga mengakibatkan kesulitan dan tragedi.

Endraswara (2008: 7-8) menjelaskan bahwa psikologi sastra dianggap penting karena karya sastra merupakan produk dari suatu keadaan kejiwaan dan pemikiran pengarang yang berada dalam situasi setengah sadar (subconsicious) setelah mendapat bentuk yang jelas dituangkan ke dalam bentuk tertentu secara sadar (conscious) dalam bentuk penciptaan karya sastra. Jadi, proses penciptaan karya sastra terjadi dalam dua tahap, yaitu tahap pertama dalam meramu gagasan dalam situasi imajinatif dan abstrak, kemudian dipindahkan ke dalam tahap kedua, yaitu penulisan karya sastra yang sifatnya 
konkritisasi apa yang sebelumnya dalam bentuk abstrak.

Konsepsi di atas dapat diasumsikan sebagai pola dan proses kreatif. Keterikatan antara psikologi pengarang dengan hasil karyanya tidak dapat dipisahkan. Proses kreatif yang dimaksud dapat meliputi seluruh tahapan, mulai dari dorongan bawah sadar yang melahirkan karya sastra sampai pada perbaikan-perbaikan terakhir yang dilakukan oleh sang pengarang. Sastra dan psikologi dapat bersimbiosis dalam perannya terhadap kehidupan, karena keduanya memiliki fungsi dalam hidup ini. Keduanya sama-sama berurusan dengan persoalan manusia sebagai makhluk individu dan makhluk sosial. Keduanya memanfaatkan landasan yang sama yaitu menjadikan pengalaman manusia sebagai bahan telaah. Oleh karena itu, pendekatan psikologi dianggap penting penggunaannya dalam penelitian sastra, sehingga terlahirlah kaidah psikologi sastra.

Kaidah psikologi sastra memandang kehidupan sebagian besar terdiri dari kenyataan sosial. Dapat dikatakan bahwa karya sastra juga "meniru" alam dan dunia subjektif manusia, sehingga sepintas cerita yang dihasilkan seperti nyata, karena karya sastra sarat dengan unsurunsur psikologis sebagai manifestasi kejiwaan pengarang berperan untuk menghasilkan figur fiksional dalam kisahan karyanya. Karya sastra sendiri terdiri dari berbagai jenis seperti puisi, novel, cerpen, dan drama. Dari karya sastra tersebut novel merupakan karya sastra yang paling populer karena lebih mudah dinikmati dan mempunyai daya komunikasi yang luas pada masyarakat. Novel dapat dijadikan sebagai sarana pembelajaran, sehingga dapat diambil manfaat dan pelajaran dalam kehidupan untuk menjadikan hidup lebih baik.

Keunikan novel "Napas Mayat" yaitu menggambarkan penyimpangan psikosis yang diderita oleh tokoh utama disebabkan oleh faktor lingkungan tokoh yang diceritakan dalam novel ini seperti membunuh, memutilasi, dan memakan daging korban-korbannya akibat ilusi dan dorongan motivasi dari tokoh bayangan yang abstrak keberadaannya. Pada beberapa kajian psikologi umum gejala seperti di atas yang dialami tokoh utama dalam novel "Napas Mayat" adalah termasuk bentuk kepribadian abnormal yang berbentuk dalam pola gangguan kecemasan. Yoseph (dalam Sobur, 2013: 343) mencoba menguraikan hubungan antara kecemasan dan ketakutan secara rinci.

Menurut Yoseph (dalam Sobur, 2013: 343) dalam rasa takut, seorang menyadari bahaya yang sedang mengancam keselamatan dirinya. Ia bahkan didorong dan diperkuat oleh situasi tersebut, sehingga akan menimbulkan reaksi paranoid. Hal ini diakibatkan oleh seseorang yang selalu dibayangi terhadap hal yang mengancam dirinya dan akan menimbulkan reaksi akhir seperti menyerang subjek yang mengancam dirinya tersebut. Unsur yang menarik dalam novel ini adalah permasalahan-permasalahan yang dimunculkan melalui narasi pengarang dan melalui dialog maupun monolog tokoh dalam cerita yang menggambarkan adanya muatan psikologi yang sangat tergambar jelas di dalamnya dengan wujud penyimpangan scizophrenia yang disebut dalam buku abnormal psycology dengan psycosis is a lack of contact with reality.

Hal tersebut yang menunjukkan munculnya ketimpangan psikologis yang menarik untuk diamati. Penyimpangan psikologis yang terjadi pada manusia dengan segala reaksi-reaksi yang ditimbulkan dalam kehidupan. Penyimpangan tersebut dapat diamati dengan kajian patologi sosial. Kajian patologi sosial ini memandang bahwa penyimpangan psikologis pada manusia dapat dikatakan sebagai status kepribadian yang kacau. Hal ini sejalan dengan pendapat Kartono (2009: 3) yang menjelaskan dan menguraikan pandangan patologi terhadap abnormalitas manusia sebagai akibat suatu kecelakaan, suatu penyakit, atau status kepribadian yang kacau (disorders state) yang dapat dijumpai pada penderita-penderita simptom klinis tertentu seperti penderita psikoneurosa dan penderita 
psikosis. Kajian patologi sosial ini dapat juga diaplikasikan terhadap karya sastra berupa novel "Napas Mayat" karya Bagus Dwi Hananto. Novel "Napas Mayat" karya Bagus Dwi Hananto merupakan novel yang tidak hanya menceritakan tentang penyimpangan psikosis tokoh utama, novel ini menitikberatkan pada gejala kejiwaan seorang tokoh yang mengalami kelainan jiwa dengan disertai proses disintegrasi kepribadian dan gangguan kontak terhadap kenyataan.

Penelitian tentang kepribadian psikologi dalam karya sastra dengan menggunakan kajian patologi sosial telah dilakukan oleh beberapa pihak. Penelitian yang dilakukan oleh Wahyuningtias (2013) yang berjudul Patologi Sosial dalam Novel di Bibirnya Ada Dusta Karya Mira $W$. Penelitian ini memfokuskan pada analisis patologi sosial berupa abnormalitas seksual, hubungan seks di luar nikah, dan mental disorder. Hasil penelitian berupa deskripsi kritis terhadap keadaan dan kehidupan tokoh Roy dalam novel ini yang mengalami abnormalitas seksual.

Penelitian yang dilakukan oleh Atrinawati (2012) yang berjudul Melawan Dampak Kapitalis Industri Hiburan di Amerika: Kajian Psikologi Tokoh Utama Novel The Rana Look Karya Sandra Brown. Penelitian tersebut menfokuskan pada konflik yang dialami oleh tokoh utamanya. Hasil penelitian berupa deskripsi mendalam mengenai kesadaran eksistensi diri tokoh Rana hingga mengalami perubahan-perubahan sikap akibat konflik-konflik yang terjadi pada diri rana dengan beberapa tokoh lainnya yang diceritakan.

Penelitian berikut dilakukan oleh Atmaja (2013) yang berjudul Analisis Psikologis Novel Sepatu Dahlan Karya Khrisna Pabichar. Penelitian tersebut menfokuskan pada sisi kejiwaan tokoh-tokoh dalam novel Sepatu Dahlan. Hasil penelitian adalah pendeskripsian yang mendalam dari analisis unsur intrinsik pembangun karya sastra untuk memperoleh gambaran-gambaran kejiwaan para tokoh-tokoh yang diceritakan dalam novel tersebut.

Kajian ilmiah yang pernah diteliti tentang kepribadian psikologi dalam karya sastra dengan menggunakan kajian patologi sosial telah dilakukan oleh beberapa pihak.

Berdasarkan penelitian terdahulu, penelitian yang akan dilakukan ini memiliki beberapa persamaan dan perbedaan, persamaan penelitian ini dengan penelitian terdahulu adalah sama-sama menfokuskan penelitian pada tokoh tertentu pada sebuah novel dengan menggunakan kajian patologi sosial dalam lingkup psikologi sastra. Namun, pada fokus masalah perbedaan yang muncul adalah kata representasi yang dilakukan pada penelitian ini, representasi yang dimaksud adalah bagaimana sebuah dunia dikonstruksi dan direpresentasikan secara sosial oleh manusia (Pujiharjo, 2010: 9).

Perbedaan lainya secara substansi atau inti, penelitian ini akan membedah psikologi tokoh dalam cerita novel "Napas Mayat" yang difokuskan pada gejala schizophrenic dengan menggunakan perspektif patologi sosial untuk menemukan gambaran gangguan kepribadian tokoh utama secara utuh. Berdasarkan hal tersebut, maka judul penelitian ini ditetapkan berupa: "Representasi Scizophrenic Tokoh Utama pada Novel Napas Mayat Karya Bagus Dwi Hananto".

\section{METODE}

Metode dalam penelitian ini menggunakan metode kualitatif dan didukung oleh pendekatan deskriptif yang digunakan untuk mendeskripsikan data penelitian yang disajikan dalam bentuk paparan data kutipan kalimat dalam satu satuan cerita yang sesuai dengan tujuan penelitian yang diamati. Sumber data penelitian adalah novel Napas Mayat karya Bagus Dwi Hananto. Data penelitian ini berupa kutipan-kutipan kalimat dalam satuan cerita yang mengandung unsur scizophrenic. Langkah-langkah analisis data meliputi: (1) membaca secara kritis novel Napas Mayat karya Bagus Dwi Hananto, (2) pengumpulan data, (3) penyajian data, (4) reduksi data, (5) penafsiran data, dan terakhir (6) penarikan simpulan 


\section{HASIL DAN PEMBAHASAN}

\section{Representasi Scizophrenic Hebefrenic}

Istilah Schizoprhenic berasal dari kata schizos: pecah belah dan phren: jiwa. Skizofrenia menjelaskan mengenai suatu gangguan jiwa yang ditandai dengan penderita mengalami perpecahan jiwa adanya keretakan atau disharmoni antara proses berpikir, perasaan dan perbuatan. Reaksi "schizophrenic" yang menyangkut proses emosional dan intelektual. Dalam karya sastra jelas pula bahwa kepribadian juga berkaitan dengan proses emosional dan intelektual yang menjadi persoalan jiwa pengarang yang asasi sehingga, pribadi pengarang akan mempengaruhi ruh karya sastranya.

Ditinjau dari perspektif patologi sosial, penyimpangan psikosis dalam wujud reaksi schizophrenic hebefrenic yang dialami oleh tokoh Aku dalam cerita berupa penyimpangan yang terjadi akibat ketidakmampuan tokoh Aku untuk menilai realita dengan fantasi dirinya. Hasil ketidakmampuan tersebut memunculkan adanya realita baru dalam diri tokoh Aku.

Pribadi tokoh Aku dalam NNM mengalami disorientasi antara pikiran realita dengan pikiran fantasinya, sehingga memunculkan adanya realitas baru yang berdampak pada disintegrasi kepribadian dalam bentuk penyimpangan. Penyimpangan tersebut tampak dalam bentuk gejala-gejala irritabel (mudah tersinggung) dan sarkasme. Hal ini tanpak dalam kutipan (B1/D1/ RRS/SH/SC 28/) berikut ini.

Pertarungan pertama dari dunia akan kuhadapi: keramaian. Dancuk! Di sanasini banyak manusia bertebaran. Aku tersesat terus. Tidak ada kebaikan setara dengan kejahatan ini. Asu! Manusia yang begitu banyak dan terus ada membuatku ingin muntah. Nausea. Aku benci semua ini setalah aku gagal di masa mudaku dulu. (B1/D1/RRS/SH/SC 28/)

Kutipan di atas, bentuk penyimpangan psikosis ditampilkan oleh tokoh Aku (tokoh utama) dalam bentuk schizophrenic hebephrenic. Reaksi penyimpangan ini dapat diperhatikan melalui kata kutipan "Dancuk!" "Asu" "Nausea". Penyimpangan psikosis dialami melalui penggunaan bahasa sarkasme dengan kata-kata makian. Kata Dancuk memiliki makna (sialan, keparat, brengsek, bangsat) ungkapan ini berupa perkataan umpatan untuk mengekspresikan kekecewaan, kata Asu berarti Anjing (dalam bahasa Jawa), sedangkan kata Nausea berarti yang menjijikkan. Ketiga penggalan kutipan di atas bermakna negatif.

Disharmoni pribadi tokoh Aku dalam $\mathrm{N} N M$ ini terhadap dunia nyata (realita) dan dunia khayal (fantasi) melahirkan pemikiranpemikiran serta tingkah laku yang abnormal yang dipicu oleh emosi kebencian (hate) yang tidak dapat dikontrol terhadap semua manusia yang memandang dirinya dengan pandangan sebelah mata. Kutipan yang mendukung adalah (B5/D2/ $\mathrm{RRS} / \mathrm{SH} / \mathrm{SC} 40 /$ ) yang menunjukkan adanya indikasi tersebut.

Bagiku tidak apa-apa. Kalian tidak bisa melukaiku. Kalian hanya sanggup berbicara denganku. Aku tidak masalah dengan hal itu. Tapi aku akan terus membunuhi manusia karena dendamku tidak bisa ditukar dengan apapun. (B5/D2/RRS/ $\mathrm{SH} / \mathrm{SC} 40 /$ )

Pada kutipan ini (B5/D2/RRS/SH/SC40/), bentuk penyimpangan psikosis ditampilkan oleh tokoh Aku (tokoh utama) dalam bentuk schizophrenic hebephrenic. Reaksi penyimpangan ini dapat diperhatikan melalui penggalan kutipan "Tapi aku akan terus membunuhi manusia karena dendamku tidak bisa ditukar dengan apapun." Penggalan kutipan ini mengindikasikan adanya penyimpangan kejiwaan dalam wujud gejala irritabel (mudah tersinggung). Penggunaan kata membunuhi (menghabisi nyawa-nyawa) adalah penanda bahasa yang menandai adanya depresi berat akibat tidak bisa mengontrol emosi secara normal. 
Tokoh Aku dalam NNM ini merupakan gambaran kepribadian manusia abnormal. Pengarang menceritakan kejiwaan tokoh Aku secara analitik dan dramatik. Secara analitik, tokoh Aku dalam NNM ini digambarkan sebagai sosok laki-laki sebatang kara yang tinggal di sebuah apartemen biasa yang mengalami gangguan kejiwaan. Reaksi pertama yang dialami oleh tokoh Aku tergambar jelas dalam wujud schizophrenic hebephrenic. Tokoh Aku dalam cerita memiliki ciri umum yang utama yakni adanya disorientasi atau kehilangan daya untuk mengenal lingkungan dan tidak dapat membedakan secara logika antara realita dan dunia fantasinya, hal ini tampak dalam kutipan monolog (B1/D3/RRS/SH/SC6/)berikut ini.

Barangkali kenangan tentang orang terkasih yang baru saja meninggal, hanya ada bagi orang-orang yang tidak tangguh. Ya. Kau manusia tangguh yang berharap bahwa dunia tidak menangkapmu di kegelapan bersama kita. (B1/D3/RRS/SH/SC6/)

Kutipan tersebut menggambarkan wujud adanya disorientasi antara dunia realita dengan dunia khayal (fantasi) dari tokoh Aku dalam NNM. Penggalan monolog tokoh Aku yang bercetak tebal Ya. Kau manusia tangguh yang berharap bahwa dunia tidak menangkapmu di kegelapan bersama kita pada kutipan (B1/D3/RRS/SH/ $\mathrm{SC6} /$ ) di atas mengindikasikan munculnya realita baru sebagai hasil ketidakmampuan tokoh Aku dalam mengenali dan membedakan antara dunia realita (nyata) dan dunia fantasi (khayal).

\section{Representasi Scizophrenic Catatonic}

Gejala schizophrenic catatonic yang dialami oleh tokoh Aku (tokoh utama) dalam NNM karya Bagus Dwi Hananto ditandai dengan reaksi autisme. Reaksi autisme yang dimaksud adalah penarikan diri atau pengasingan diri dengan cara mengisolasi diri dari kehidupan sosial dan lebih senang hidup dalam dunia khayalnya, sehingga tokoh Aku dalam NNM mengalami deteriorasi mental (kemerosotan/ kemunduran) dari taraf fungsi penyesuaian (adaptasi) diri dengan kehidupan sosialnya, sehingga menyebabkan kehidupan tokoh Aku dalam NNM menjadi pasif dan apatis. Hal ini dapat diperhatikan melalui kutipan (B1/D4/RRS/ $\mathrm{SCa} / \mathrm{SC} 7-8$ ) berikut.

Benar tidak usah meyakini Tuhan berarti kau menjadi seorang yang benar-benar bebas. Sebenarnya kau sudah tersisih dari dunia ini.

Yang paling mencintai diriku adalah diriku sendiri. Manusia hidup mencari kebahagiaan meski hakikatnya kebahagiaan itu bisa ditemukan di tubuh mereka sendiri. (B1/D4/RRS/SCa/SC 7-8)

Hal yang dapat dijelaskan pada kutipan (B1/ D4/RRS/SCa/SC 7-8) ini, adalah adanya bentuk penyimpangan yang ditampilkan oleh tokoh Aku (tokoh utama) dalam bentuk schizophrenic catatonic. Reaksi penyimpangan ini dapat diperhatikan melalui penggalan kutipan "Yang paling mencintai diriku adalah diriku sendiri". Penggalan kutipan ini mengindikasikan adanya gangguan akibat gejala autis dan terganggunya prilaku hubungan dengan orang lain di sekitarnya, sehingga tokoh Aku merasa tidak membutuhkan orang lain dalam kehidupannya.

Penyimpangan schizophrenia dalam bentuk katatonik yang dialami tokoh Aku dalam NNM ini diakibatkan oleh adanya proses penarikan diri tokoh Aku ke dalam dunia khayalnya, sehingga menyebabkan timbulnya gejala autisme yang berindikasi terhadap terjadinya deteriorasi fungsi adaptasi sosial. Hal ini dapat diperhatikan dalam kutipan isi novel (B1/D5/RRS/SCa/SC 1-2/) berikut.

Siapa aku? Manusia selalu terkejut melihat
dia berubah dari waktu ke waktu. Hanya
buram dan titik-titik semut di televisi di
dalam tubuh lama dan baru ini.
Saat kau meninggalkan dunia. Kau bagai
anak tangguh yang berusaha tidak 
mencari pegangan apapun. Lalu orangorang mulai mencampakkanmu dan menjulukimu sebagai si aneh ketika kau kembali kepada dunia yang ini. Kau bungkam dan berhenti untuk mencintai apapun... (B1/D5/RRS/SCa/SC 1-2/)

Pada kutipan ini, bentuk penyimpangan psikosis ditampilkan oleh tokoh Aku (tokoh utama) dalam bentuk schizophrenic catatonic. Reaksi penyimpangan ini dapat diperhatikan melalui dua penggalan kutipan "Siapa aku?" dan "Kau bagai anak tangguh yang berusaha tidak mencari pegangan apapun." Kedua kutipan ini merupakan wujud monolog atau pembicaraan tokoh dengan dirinya sendiri. Kalimat tanya "siapa aku?" pada kutipan ini merupakan bentuk gejala autisme yang diperkuat oleh pernyataan "Kau bagai anak tangguh yang berusaha tidak mencari pegangan apapun". Kedua kalimat ini bersimbiosis dan mengindikasikan adanya gejala autisme atau penarikan diri dari ke dalam dunia fantasi sendiri atau mengasingkan diri (withdrawn) yang dicirikan dengan kebiasaan melamun (day dreaming).

Bentuk penyimpangan ini dialami oleh tokoh Aku sebagai wujud dari ketidakmampuan dirinya bersosialisasi dengan lingkungan sosial. Hal ini dilakukan oleh tokoh Aku dengan alasan bahwa dirinya serta kehidupannya penuh dengan kekurangan-kekurangan yang mampu menjadikan dirinya menjadi bahan cemoohan masyarakat luar. Namun, dukungan dari tokoh Si Hitam dalam cerita yang merupakan jelmaan gangguan kejiwaan tokoh Aku (tokoh utama) dengan segala dorongan-dorongan negatif yang menjadikan pola tingkah laku tokoh Aku menjadi pribadi yang negativisme dan autis. Data tersebut menunjukkan adanya dorangan stimulus dari segi id yang memiliki prinsip kesenangan belaka (pleasure principle) yang menyebabkan adanya gangguan kejiwaan akut.

\section{Representasi Scizophrenic Paranoid}

Gejala schizophrenic paranoid yang dialami oleh tokoh Aku (tokoh utama) dalam NNM karya Bagus Dwi Hananto ditandai dengan reaksi gangguan waham, halusinasi, dan delusi kematian. Ketiga reaksi yang mengindikasikan gejala psikosis pada tingkatan schizophrenic paranoid ini saling mempengaruhi dan mendominasi kejiwaan alam bawah sadar tokoh Aku dalam NNM. Hal ini dapat diperhatikan melalui kutipan (B2/D6/RRS/SP/SC 41/) berikut ini.

"Kembalikan aku pada tubuhku!" kata Mama Besar, marah. Aku terperanjat, mundur ke belakang dan sedikit ketakutan.

"Kembalikan aku pada tubuhku, biadab aneh. Kau kampret botak!"

Dengan terbata-bata, aku menjawabnya, "Bagaimana kau bisa bicara di dalam toples itu?"

"Yang jelas kembalikan aku pada tubuhku. Di dalam perutmu ada tubuhku! Aku akan memintanya kembali! Kau harus membayar dosa gilamu ini” (B2/D6/RRS/SP/SC 41/)

Data yang tertera Pada kutipan (B2/D6/ $\mathrm{RRS} / \mathrm{SP} / \mathrm{SC} 41 /$ ), bentuk penyimpangan psikosis ditampilkan oleh tokoh Aku (tokoh utama) dalam bentuk schizophrenic paranoid. Reaksi penyimpangan ini dapat diperhatikan melalui penggalan kutipan "Bagaimana kau bisa bicara di dalam toples itu?". Penggalan kutipan ini mengindikasikan adanya penderitaan yang dialami tokoh $\mathrm{Aku}$ dengan diliputi halusinasi (pengalaman panca indra tanpa ada ransangan) dengan ciri bahasa yang dimainkan pengarang dengan cara memenggal pronomina "Bagaimana" menjadi "Bagaimana", pemenggalan inilah yang mengindikasikan adanya kekacauan pikiran dalam wujud halusinasi terhadap sesuatu.

Penyimpangan schizophrenia dalam bentuk paranoid yang dialami tokoh Aku dalam NNM karya Bagus Dwi Hananto ini diakibatkan oleh adanya dominasi elemen Id yang berada di bawah alam tak sadar tokoh Aku yang 
memberikan dorongan-dorongan negatif berupa gangguan waham dan halusinasi, sehingga menimbulkan efek kecemasan dan berujung pada pola penyimpangan akibat munculnya khayalan (delusi) kematian. Hal ini dapat diperhatikan dalam kutipan (B1/D7/RRS/SP/SC 3-4) berikut.

Itu adalah kematian panjang yang mesti aku jalani; kematian yang kudapat di dunia ini meskipun aku masih hidup.

Kau tahu, sesungguhnya Tuhan telah mati bagi mereka yang kecewa. Bagi dirimu dan bagiku yang kita. Tidak ada apapun di luar sana. Hanya kekosongan. (B1/D7/ RRS/SP/SC 3-4)

Pada kutipan ini, bentuk penyimpangan scizophrenic yang ditampilkan oleh tokoh Aku (tokoh utama) dalam bentuk schizophrenic paranoid. Reaksi penyimpangan ini dapat diperhatikan melalui penggalan kutipan "Itu adalah kematian panjang yang mesti aku jalani” Penggalan kutipan ini mengindikasikan adanya delusi (khayalan) tentang kematian. Delusi kematian dalam dunia psikologi adalah akibat dari pemaknaan hidup yang gagal dan diiringi dengan rasa kecemasan yang akan menimbulkan rasa kesepian dan kekosongan pada akhirnya berujung pada pikiran tentang kematian.

Delusi-delusi (khayalan) tentang kematian yang dialami tokoh Aku (tokoh utama) dalam NNM adalah akibat dari gangguan waham atau keyakinan yang tidak rasional tokoh Aku terhadap kehidupan. Hal ini dapat diperhatikan melalui kutipan (B1/D8/RRS/SP/SC 43/) berikut.

Benar kata si Hitam. Sejak sebermula, kemanusiaan sudah mati. Kemanusiaan tenggelam bersama perubahan zaman yang menyelipkan berbagai alasan sok rasional dan akhirnya dilupakan oleh manusia itu sendiri. (B1/D8/RRS/SP/SC 43/)

Pada kutipan ini, bentuk penyimpangan psikosis ditampilkan oleh tokoh Aku (tokoh utama) dalam bentuk schizophrenic paranoid. Reaksi penyimpangan ini dapat diperhatikan melalui penggalan kutipan "kemanusiaan sudah mati. Kemanusiaan tenggelam bersama perubahan zaman”. Kutipan ini menandakan adanya gangguan waham atau persepsi yang tidak sesuai dengan logika akibat implus-implus negatif yang berasal dari dalam dirinya sendiri, sehingga beranggapan segala sesuatunya akan bertentangan dengan dunia nyata. Tokoh Aku (tokoh utama) dalam hal ini menjadi orang yang introvet (tertutup) dari dunia sosial.

Dalam menggarisbawahi unsur kegilaan yang berupa gejala schizophrenic paranoid sesuai dengan perspektif patologi sosial terhadap kejiwaan tokoh Aku (tokoh utama) dalam NNM karya Bagus Dwi Hananto ini dapat ditinjau dari tiga elemen dasar kejiwaan manusia yang meliputi id, ego, dan superego yang saling bertentangan dan membentuk pola kepribadian dan kejiwaan tokoh Aku (tokoh utama) dalam NNM yang berbentuk pertentangan antara nurani dan nafsu (perspektif agama). Hal ini dapat dipertegas melalui penggambaran bagan kejiwaan tokoh Aku berikut.

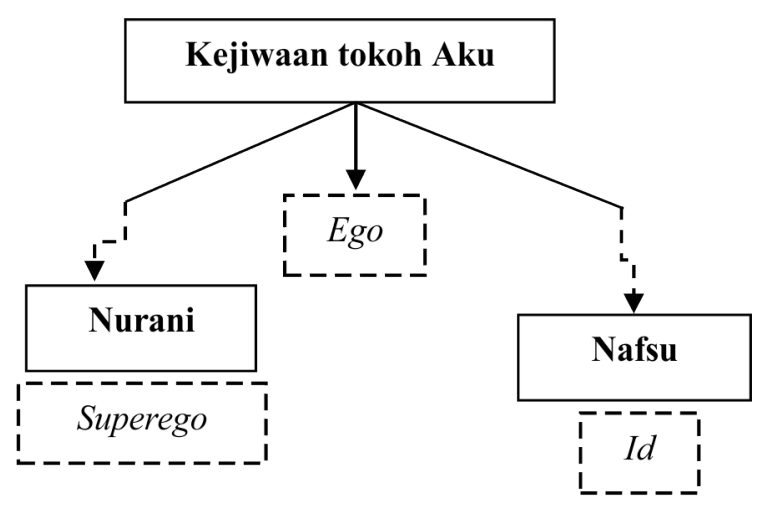

Gambar 1. Elemen Kejiwaan Tokoh Aku dalam Novel Napas Mayat Karya Bagus Dwi Hananto

Kegilaan atau keabnormalitasan tokoh Aku dalam NNM ini terbentuk atas dasar pertentangan antara elemen jiwa nurani (superego) dan nafsu (id) yang terjadi di dalam kejiwaannya sendiri (ego). Hal ini dipertegas melalui kutipan (B5/ D9/RRS/SP/SC 49) berikut. 
Walaupun aku berusaha mengentaskan diriku keluar dari pikiranku. Aku tidak bisa. Ada aku yang lain yang memaksaku tetap pada jalan yang kupilih sebelumnya. Aku yang bergelut di dalam kesadaranku dan menawarkan berbagai opsi yang dapat kuambil. Aku yang pertama dan aku diriku yang ada di dalamku berkelahi. (B5/D9/RRS/SP/SC 49/)

Kutipan (B5/D9/RRS/SP/SC 49/), menyatakan bentuk penyimpangan psikosis yang ditampilkan oleh tokoh Aku (tokoh utama) dalam bentuk schizophrenic paranoid. Reaksi penyimpangan ini dapat diperhatikan melalui penggalan kutipan "Aku yang pertama dan aku diriku didalamku berkelahi" pada penggalan kutipan ini mengindikasikan adanya gangguan waham yang berat dan dapat diartikan pula, dalam kepribadian yang terpecah menjadi dua sisi (Aku yang pertama dan aku diriku) mengalami disharmonisasi, sehingga keduanya saling melawan. Dalam kijiwaan manusia adanya nurani (Superego) dan nafsu (Id) yang saling berlawanan akan terus memberikan dorongan kepada akal manusia (Ego). Ketika ego tidak mampu mengontrol kedua dorongan yang saling bertentangan ini maka memicu terjadilah penyimpangan-penyimpangan atau kegilaan.

\section{KESIMPULAN}

Berdasarkan hasil penelitian dan pembahasan pada bab sebelumnya mengenai representasi scizophrenic tokoh Aku dalam novel Napas Mayat karya Bagus Dwi Hananto dengan ditandai adanya reaksi-reaksi kejiwaan abnormal yang ditinjau melalui perspektif patologi sosial. Secara lebih jelas dan konkrit, simpulan hasil analisis dipaparkan sebagai berikut.

Representasi reaksi schizophrenic yang dialami dalam tiga wujud reaksi, di antaranya (1) schizophrenic hebephrenic, berupa penyimpangan yang terjadi akibat ketidakmampuan tokoh Aku untuk menilai realita dengan fantasi dirinya, sehingga memumculkan adanya tokoh Aku, (2) schizophrenic catatonic, berupa penyimpangan yang terjadi akibat adanya proses penarikan diri tokoh Aku ke dalam dunia khayal. Gejala autis yang berindikasi terhadap terjadinya deteriorasi fungsi adaptasi sosial. (3) Schizophrenic paranoid, berupa penyimpangan yang terjadi akibat adanya dominasi elemen id yang berada di bawah alam tak sadar dan memberikan dorongan negatif berupa gangguan waham dan halusinasi, sehingga menimbulkan efek kecemasan dan berujung pada munculnya delusi kematian.

\section{DAFTAR PUSTAKA}

Atmaja, L. K. (2013). Analisis Psikologis Novel "Sepatu Dahlan" Karya Khrisna Pabichara. Bengkulu: Universitas Bengkulu.

Atrinawati. (2012). Melawan Dampak Kapitalitas Industri Hiburan di Amerika: Kajian Psikologi Tokoh Utama Novel The Rana Look Karya Sandra Brown. Semarang: Universitas Diponegoro.

Endraswara, S. (2008). Metode Penelitian Psikologi Sastra: Teori, Langkah, dan Penerapannya. Yogyakarta: FBS Universitas Negeri Yogyakarta.

Kartono, K. (2009). Psikologi Abnormal dan Abnormalitas Seks. Bandung: CV. Mandar Madju.

Pujiharjo. (2010). Perubahan Puitika dalam

Fiksi Indonesia dari Modernisme ke

Pascamodernisme. Yogyakarta: Elmatera.

Sobur, A. (2013). Psikologi Umum dalam Lintasan Sejarah. Bandung: Pustaka Setia. Suyasa, M. (2004). Pengantar Teori Sastra. Mataram: Universitas Muhammadiyah Mataram Press.

Wahyuningtias, $R$. (2013). Patologi Sosial dalam Novel di Bibirnya Ada Dusta Karya Mira Widjaja. Jember: Universitas Jember. 